\title{
Social Technologies for Management: Opportunities for Coal-mining Enterprises
}

\author{
Zonova Olga V., Slesarenko Ekaterina V. ${ }^{\text {b }}$ \\ T. F. Gorbachev Kuzbass State Technical University \\ Kemerovo, Russian Federation \\ aiamzonova@gmail.com, bslekvlad@mail.ru
}

\author{
Nekhoda Evgeniya V. \\ National Research Tomsk State University \\ Tomsk, Russian Federation \\ sheyna@sibmail.com
}

\begin{abstract}
The ways of improving the social management technologies, including those for the coal-mining enterprises, in particular the development of the corporate social responsibility, especially in the labor relations system, are proposed in the article. Ignoring the challenges of the contemporary reality, in particular, to overcome the decent work deficit in favor of shortterm profits is fraught with the degradation of the economy and the labor force. For which reason, the authors have developed methodological approaches to the development of the system of working life quality standards, including the social and labor standards of amount, ratio, time / term and the social and labor quality standards. The active social and labor standards recommended by the International Labour Organization, the European Social Charter, the International Covenant on Economic, Social and Cultural Rights, are divided into two groups: the area of wages and the area of social security; aggregated into the Working life quality standard. The opportunities and the constraints of the implementation of social standards and the corporate social responsibility increase are found.
\end{abstract}

Keywords: social and labour relations; corporate social responsibility; working life quality; partnership; employees; social safety; social standards

\section{INTRODUCTION}

In recent years, the social technologies based on multidisciplinary researches are actively developed in the theory and practice of management. The example of such a technology is the corporate social responsibility, first of all, in the system of social and labor relations [1, pp. 147-151;2, pp. 63-69; 3, pp. 42-45; 4 and others].

Social and labor relations have come a long way of evolutionary development from discrimination, confrontation, competition and paternalism to partnership. The current stage of their development can be characterized by the processes of socialization, the development of new social roles and functions for each of the parties (government, business and workers) of labor relations. For business - it is the role of a socially responsible company.

The issue of corporate social responsibility involuntarily arises due to the fact that the average size of wages in Russia is a little more than three minimum living wages of the laborcapable population, that indicates the "labor poverty" and entails at least two more facts of social injustice: the growth of demand in the low salary labor market and the growth of informal employment [5]. The understated wages undermine the normal process of labor force reproduction and present a powerful constraint of the purchasing power growth and, consequently, the further development of production $[6$, p. 73 ; 7 , pp. $22-23 ; 8$, p. 212]. In addition, the understated minimum wage actually cancels the 40-hour working week, as a person who has worked in this period the standard working time and met the labor quota, cannot ensure their livelihoods at a minimum level. This not only violates the principles of social justice and the legally approved labor standards, but also the targets of decent work concept, forcing the qualified staff to seek additional work to the detriment of their professional qualification development whereas the creation of decent working conditions and social guarantees entail the economic benefits in the long term and provide the long-term sustainable development of production [9]. Accordingly, the companies that refuse to take on social responsibility suffer the indirect losses in the form of lost human capital investment profits [10].

The social responsibility of businesses is defined as the corporation obligation to benefit society by directing a part of its profit to solve the acute social problems [1, p. 148]. In management theory the most commonly used term is the "corporate social responsibility', which is understood as an independent concept of a voluntary company care about its employees, the environment, the areas of corporate operations, taking into account the interests of the company stakeholders [2, p. 63; 3, pp. 42-43]. Strizhov S. defines the corporate social responsibility as follows: "The corporate social responsibility is considered as a concept that reflects the good-voluntary decision of the company to participate in the improvement of social development processes and the environmental protection" [4, p. 23].

The main areas of activity for the corporate social responsibility are mainly the following: environmental management and resource conservation; development of the areas of corporate operations; protection of the health of workers and the establishment of safe jobs and decent working conditions; staff development by channeling the investments to their qualification improvement, training and retraining of the enterprise workers. The implementation of these activities can be done only by the large companies, or branches and offices of multinational companies. The possible barriers to becoming a socially responsible business are: 1) reduction in performance efficiency, including in coal mining, due to the 
introduction of sanctions against the Russian Federation, decrease in prices for their production at the world market, etc.; 2) the advisory nature of conventions of the International Labour Organization and the absence of the legislative initiative to ratify a number of conventions in the Russian Federation.

Is the partnership mutually beneficial in the system of labor relations and is the business socially responsible? Getting the substantiated answer to this question is the aim of the research conducted. Achieving this goal involves the solution of the following issues: 1) analysis of corporate social responsibility policy of the Russian coal mining enterprises; 2) aggregation of social and labor standards, recommended by the regulations of the leading international organizations into the standard for the quality of employee working life; 3) the comparison of corporate social policy targets with social and labor regulations recommended by the International Labour Organization.

\section{METHODS}

As a part of the corporate social responsibility, it is advisable to establish the criteria indicators, which the company is to achieve in the labor relations system; the use of extrapolation methods being ineffective, since the continuation of the past trends is severely restricted in terms of social rationing [11]. In this connection, the main method for the development of social and labor standards is the standard method, rather than the method of performance-based planning.

\section{RESULTS}

The corporate social responsibility in labor relations is now reduced in most cases to the explicit declaration of the creation of safe workplaces and taking care of the health of workers and the regulation of wages and the promotion of productive employment. Whereas in fact it is possible to note the negative trends in this area, as evidenced by the presence of low wages and poor working conditions; many companies provide their workers with the social services on a voluntary basis (taking care of the health of employees, their children's vacations, company's pensioners), without fixing it in the collective agreements [12]. This means that at any time the employer may deny to provide the employee with such services, which raises the question of the effectiveness of the interaction of the social partners.

We find the way out of the situation in the development of the unified standards in the field of social and labor relations and the employees' working life quality. This is due to the fact that, firstly, the majority of people are psychologically predisposed to compare their own living conditions with the living conditions of people with a higher standard of living; secondly, the influence of the social environment can lead to suppression of their dissatisfaction; thirdly, the life under the certain conditions suggests to the development of new evaluation standards [13, p. 196; 14, pp. 90-91].
So far, the researchers in the field of economy have not differentiated such concepts as "norm", "regulation" and "standard" with regard to the social and labor sphere. In this connection, we consider it expedient to identify the essence of these concepts. Thus, according to V.I. Dahl explanatory dictionary, the norm - is "a general rule, which should be followed in all similar cases; sample or example. The normal state, usual, lawful, proper, not coming out of order, not falling into any extreme,"[15]. It is important to emphasize that the standard - is not a subjective view, but the "exact prescription" or the "legalized decision" [16, pp. 733-734]. Moving from the general to the particular, the authors of the study understand the social and labor standards as the set of regulations and rules established by the public authorities that determine the patterns of life of individuals in the labor process.

The regulation is commonly understood as the general measure of consumption and the use of different resources, and occasionally the establishment of the limits of consumption / use: it can be the minimally acceptable threshold, the upper limit, etc. With regard to the social and labor standards, the most widely used notions are currently the following: minimum wage, living wage, consumer basket, minimum consumer budget, disability-hiring quotas. Their fragmentary nature is obvious.

The set of social and labor standards regulating the different aspects of quality of the working life of employees is the Standard of corporate social responsibility. This Standard should be based on the active labor legislation (ratified International Labour Organization convents, the Labour Code of the Russian Federation, Sectoral agreements and so forth.). The introduction of such standards will help to create the decent work conditions.

We consider it appropriate to base the development of methodological approaches to standardization on the following classification of the applicable rules: 1) the quantity standards (minimum wage, living wage, the minimum amount of paid social benefits, etc.); 2) quality standards (equal pay for work of equal value without any discrimination, ensuring the continuous professional development of the employee; the real participation of employees in the production management, etc.).; 3) ratio standards (the ratio between the gross wage rate and the living wage rate, the ratio of the minimum wage to the average gross wage, the ratio of persons with disabilities to the average number of employees, the ratio of the average value of income of $10 \%$ of the most affluent segment of the population to the per capita income of the poorest $10 \%$ of the population); 4) time / timing standards (working hours, the frequency of vocational education and training, retirement age) [17]. And their quantification should be charged to the specialized agencies such as the Federal Service for Labour and Employment, Ministry of Health, Ministry of Labour and Social Protection of the Russian Federation, the International Labour Organization Bureau and other services and departments interested in the protection of the interests of workers. 
According to the analysis of existing international and Russian practices of social and labor standards, the authors attempted to aggregate all the information available at this stage of society development into the Standard of working life quality (see Table). The proposed system of social and labor standards is not exhausted, and includes only: 1) social and labor standards in the field of wages, and 2) the social and labor standards in the field of social security.

TABLE I. QUALITY STANDARD FOR THE EMPLOYEE'S WORKING LIFE

\begin{tabular}{|c|c|c|}
\hline \multirow[b]{2}{*}{$\begin{array}{c}\text { Standard } \\
\text { components }\end{array}$} & \multicolumn{2}{|l|}{ Rules and regulations } \\
\hline & $\begin{array}{l}\text { Recommendations of International } \\
\text { Labour Organization, the clauses } \\
\text { of European social charter (not } \\
\text { ratified by RF), International } \\
\text { Covenant on Economic, Social and } \\
\text { Cultural Rights (ratified by RF) }\end{array}$ & $\begin{array}{c}\text { Russian } \\
\text { experience }\end{array}$ \\
\hline \multicolumn{3}{|c|}{ Social and labour standards concerning the wages } \\
\hline $\begin{array}{c}\text { Living wage of } \\
\text { able-bodied } \\
\text { population }\end{array}$ & $\begin{array}{l}\text { Covenant of International Labour } \\
\text { Organization № 117, Covenant of } \\
\text { International Labour Organization № } \\
\text { 82. Calculating the living wage such } \\
\text { basic needs of employee's families as } \\
\text { food, its calorific value, dwelling, } \\
\text { clothes, health services and education } \\
\text { should be taken into the } \\
\text { consideration }\end{array}$ & $\begin{array}{c}\text { The living } \\
\text { wage on the } \\
\text { basis of the } \\
\text { consumer } \\
\text { basket [13], } \\
\text { which } \\
\text { includes both } \\
\text { food and non- } \\
\text { food goods } \\
\text { and services } \\
{[14]}\end{array}$ \\
\hline $\begin{array}{c}\text { Minimum } \\
\text { consumer } \\
\text { budget }\end{array}$ & $\begin{array}{c}\text { Covenant of International Labour } \\
\text { Organization № } 131 \text { «Wage } \\
\text { determination with special reference } \\
\text { to developing countries» (not ratified } \\
\text { by RF) }\end{array}$ & $\begin{array}{l}\text { Not applied in } \\
\text { the majority of } \\
\text { constituent } \\
\text { entities of RF }\end{array}$ \\
\hline $\begin{array}{l}\text { Minimum } \\
\text { wage }\end{array}$ & $\begin{array}{l}\text { International Covenant on Economic, } \\
\text { Social and Cultural Rights of 1966: } \\
\text { the employees are entitled to salary, } \\
\text { providing the decent living for } \\
\text { themselves and their families. In } \\
\text { accordance with the recommendation } \\
\text { of International Labour Organization } \\
\text { № } 135 \text { "Wage determination with } \\
\text { special reference to developing } \\
\text { countries", the following criteria are } \\
\text { applied in determining the minimum } \\
\text { wage level: a) the needs of workers } \\
\text { and their families; b) the general } \\
\text { level of wages in the country; c) cost } \\
\text { of living, etc. } \\
\text { Minimum wage = } 40 \% \text { of average } \\
\text { wage }\end{array}$ & $\begin{array}{l}\text { Minimum } \\
\text { wage }=\text { living } \\
\text { wage of able- } \\
\text { bodied } \\
\text { population } \\
\text { [15] }\end{array}$ \\
\hline $\begin{array}{l}\text { Relationship } \\
\text { between the } \\
\text { average } \\
\text { nominal gross } \\
\text { payroll and the } \\
\text { minimum } \\
\text { subsistence } \\
\text { level } \\
\text { for the able- } \\
\text { bodied } \\
\text { population }\end{array}$ & Not applied & $\begin{array}{l}\text { In a number of } \\
\text { sectoral } \\
\text { agreements, } \\
\text { the minimum } \\
\text { size of the } \\
\text { average wage } \\
\text { is established } \\
\text { at the level of } \\
4-5 \text { living } \\
\text { wages of able- } \\
\text { bodied } \\
\text { population, } \\
\text { but the six- } \\
\text { fold average } \\
\text { monthly wage } \\
\text { excess over } \\
\text { minimum }\end{array}$ \\
\hline
\end{tabular}

\begin{tabular}{|c|c|c|}
\hline \multirow[b]{2}{*}{$\begin{array}{l}\text { Standard } \\
\text { components }\end{array}$} & \multicolumn{2}{|l|}{ Rules and regulations } \\
\hline & $\begin{array}{l}\text { Recommendations of International } \\
\text { Labour Organization, the clauses } \\
\text { of European social charter (not } \\
\text { ratified by RF), International } \\
\text { Covenant on Economic, Social and } \\
\text { Cultural Rights (ratified by RF) }\end{array}$ & $\begin{array}{c}\text { Russian } \\
\text { experience }\end{array}$ \\
\hline \multicolumn{3}{|c|}{ Social and labour standards concerning the wages } \\
\hline & & $\begin{array}{l}\text { subsistence } \\
\text { level is } \\
\text { considered to } \\
\text { be the most } \\
\text { appropriate } \\
\text { [16] }\end{array}$ \\
\hline $\begin{array}{l}\text { Relationship } \\
\text { between the } \\
\text { minimum wage } \\
\text { and the average } \\
\text { wage (Kaitz } \\
\text { index) }\end{array}$ & $\begin{array}{l}\text { The minimum level established in } \\
\text { this regard by the European } \\
\text { Committee of Social Rights is } 60 \%\end{array}$ & Not applied \\
\hline $\begin{array}{l}\text { Income } \\
\text { inequality }\end{array}$ & $\begin{array}{c}\text { The revenues of } 10 \% \text { of the most } \\
\text { affluent citizens of the country } \\
\text { should not exceed more than } 10 \\
\text { times the incomes of the poorest } 10 \% \\
\text { [17] }\end{array}$ & $\begin{array}{l}\text { The value of } \\
\text { R/P } 10 \% \text { ratio } \\
\text { not more than } \\
10-16 \text { times is } \\
\text { set forth in } \\
\text { various } \\
\text { sectoral } \\
\text { agreements }\end{array}$ \\
\hline \multicolumn{3}{|c|}{ Social and labour standards concerning the social security } \\
\hline $\begin{array}{l}\text { Pension } \\
\text { replacement } \\
\text { ratio }\end{array}$ & $\begin{array}{c}\text { According to Covenant of } \\
\text { International Labour Organization } \\
\text { «Minimal standards of Social } \\
\text { security» № (1952) replacement ratio } \\
\text { should be not less than } 40 \% . \\
\text { Covenant of International Labour } \\
\text { Organization "Mobility allowances, } \\
\text { retirement and survivor benefits” № } \\
128 \text { (1967) determined the } \\
\text { recommended 45\% level of } \\
\text { retirement pension }\end{array}$ & Not applied \\
\hline
\end{tabular}

The data analysis allows to draw the following conclusion: many of the recommended social and labor standards are not laid in the foundation of the Russian labor legislation, sectoral agreements, and the corporate social responsibility, which creates the opportunities for the business to give the preference to the short-term profits in the current period, rather than technical modernization of production and human development. For example, a leading Russian coal mining company "SUEK" JSC follows all of the above lines of activity of corporate social responsibility. It is also undeniably positive in terms of social security to sign medium-term Federal trade agreement for the coal industry for a number of years, according to which the minimum wage is established in accordance with the procedures stipulated in the collective bargaining agreements, but not below the subsistence level in the corresponding constituent entity of the Russian Federation. However, the given amount of social guarantees is far from the optimal values, this indicates that the salary does not perform its reproductive function, since the minimum wage in Russia is set without taking into account the dependency burden, despite the International Labour Organization recommendations. The experience of some European countries, providing the increased social guarantees relating to health, 
safety and welfare of employees of the coal industry, [22], to overcome the deficit of decent work and enhance the quality of working life, is indicative.

\section{Discussions}

Despite the facts that the concept of Decent Work has become the part of the Millennium Development Goals in the UN Declaration and many countries signed the fundamental International Labour Organization conventions, the opportunity to overcome the decent work deficits through the social standards for the labouring class of the planet is very distant because of the following reasons: firstly, the International Labour Organization is unable to induce the legally binding compliance with its standards and there is a danger of co-opting the idea of decent work by some elitist organizations; second, they cannot explain the real reasons of "indecent" labor; and, that is the most crucial, poorly understands the class relations under capitalism [23].

Consequently, the conceptualization should start with the analysis of social and labor relations in the conditions of competition and natural market. The labor management in such conditions is aimed at maximizing the speed and intensity of the implementation of production tasks, i.e. at increasing the labor productivity. Businesses continuously reorganize "the balance of power system... to define and enforce the labor discipline" [24], which explains why the capital will try to minimize or completely eliminate, the actions of the workers, which may limit its profits. This fact is indicated by G. Savin, arguing that recently there has been an unprecedented attack of the global business structures on the fundamental labor rights of workers [25].

The authors share the view of B. Slevin concerning the fact that all the institutional agreements between business, workers' representatives and the government achieved so far - are "the result of the struggle from below" [23], taking sometimes the form of the revolutionary movement. Apparently, this is the only effective measure under the prevailing conditions of natural market.

\section{CONCLUSION}

Currently, the stakeholders, primarily the owners and company management should start thinking about the future, because in the conditions of depopulation and availability of traditional resources, it is the employees who are the basis for organization development. In connection with this the age-old dilemma of "social justice - market efficiency" should be considered as a source of long-term competitive advantage. We consider it appropriate to use the proposed theoretical and methodological approaches to the creation of a system of working life quality standards for the development of sectoral trade agreements and corporate social responsibility standards. The study led to the conclusion that the achievement of the strategic objectives of the coal-mining companies, including those included in the long-term program of the Russian coal industry development for the period until 2030 (improving the efficiency of the "living" labor) is possible by increasing the amount of social guarantees for the purpose of leveling the social tensions and reducing the social risks at workplaces and in the coal-mining areas.

\section{REFERENCES}

[1] Nekhoda E. V. Vliyanie sotsialnoy otvetstvennosti biznesa na razvitie trudovykh otnosheniy [Influence of social responsibility of bisness to development of socio-labour relations]. Vestnik Tomskogo gosudarstvennogo universiteta [Bulletin of Tomsk State University]. 2008. \# 314. pp: 147-151.

[2] Kostin A. Korporativnaya sotsialnaya otvetstvennost: mirovoy opyt i kontseptsiya dlya Rossii [Corporate Social Responsibility: global experience and concept for Russia]. Strategii Rossii [Russian Strategy]. 2004. \# 2. pp: 63-69.

[3] ES: podderzhka printsipov korporativnoy sotsialnoy otvetstvennosti [EU: support corporate social responsibility principles]. Chelovek i trud [Man and labor]. 2003. \# 2. pp: 42-45.

[4] Strizhov S. A. Formirovanie i razvitie sistemy korporativnoy sotsialnoy otvetstvennosti $\mathrm{v}$ sovremennoy ekonomike Rossii [Formation and development of system of corporate sotsicial responsibility in the modern economy of Russia]. Avtoreferat dissertatsii doktora ekonomicheskikh nauk [Abstract of the thesis of the doctor of economic sciences]. Moskow, 2007. 47 p.

[5] Andreeva E. L., Polkova T. V. The estimation of labor life quality in regions of Russia. Ekonomika regiona [The region's economy]. 2013. \# 3. pp: 91-100.

[6] Shaymardanov N. Z. Institut dostoynogo truda v kontekste regionalnykh rynochnykh preobrazovaniy [Decent Work Institute in the context of the regional market transformation]. Vestnik Chelyabinskogo gosudarstvennogo universiteta [Bulletin of the Chelyabinsk State University]. 2011. \# 251. pp: 71-74.

[7] Bereznev S. V., Kudrevatykh N. V. Theoretical and practical bases of an assessment of poverty in Russia // Journal of Economy and entrepreneurship. 2014. \# 8 (2). pp: 17-23.

[8] Zhernov E. E., Nekhoda E. V. Komparativnyy analiz sovremennogo sostoyaniya ekonomiki znaniy $\mathrm{v}$ resursodobyvayushchikh regionakh Tomskoy i Kemerovskoy oblastyakh [The comparative analysis of the current state of knowledge in the economy of resource regions - the Tomsk and Kemerovo regions].Vestnik Kuzbasskogo gosudarstvennogo tehnicheskogo universiteta [Bulletin of Kuzbass State Technical University]. 2015. \# 6. pp: 206-215.

[9] Cwik N. Corporate social responsibility and innovations. In: M. Bernatt, J. Bogdanienko, T. Skoczny (Eds.). Społeczna odpowiedzialnosc biznesu. Krytyczna analiza. WN WZ UW, Warszawa, 2011. pp: 157182.

[10] MacGregor S. P., Fontrodona J. Social innovation: Using design to generate business value through corporate social responsibility. 16th International Conference on Engineering Design, ICED, 2007. pp: 1-12.

[11] Andronova A. A. Social standardize the system of regional development [Socialnaya standartizatsiya $\mathrm{v}$ sisteme regionalnogo razvitiya]. URL: www.idmrr.ru/downloads/konkurs/Andronova.doc (accessed: 28.02.2016).

[12] Baikal forum. Discussion of the economic consciousness of the population of Russia [Obsuzhdenie razvitiya ekonomicheskogo soznaniya naseleniya Rossii]. URL: http://ikunak.ru/news/2006/9/20/42973 (accessed: 29.02.2016).

[13] Kulikov N.I., Vdovina E.S. Assessment of Life Quality of the Region's Population // Problems of Contemporary Science and Practice. 2010. \# 7-9 (30). P. 194-203.

[14] Fakhrutdinova E., Kolesnikova J., Safina L., Mikhailov F. World Applied Sciences Journal, 27 (2013): 87-91. doi: 10.5829/idosi.wasj.2013.27.emf.18.

[15] Dal V. I. Explanatory Dictionary of Russian language [Tolkovyj slovar zhivogo velikorusskogo yazyka]. URL: http://www.classes.ru/allrussian/russian-dictionary-Dal-term-19935.htm (accessed: 29.02.2016).

[16] Eisler R. Wörterbuch der philosophischen Begriffe, Band 1. Berlin. 1904. pp: 733-734. 
[17] Nefedeva E. I. Working life quality standards and mechanisms of their provisions [Standarty kachestva $\mathrm{v}$ oblasti zanyatosti naseleniya i mekhanizmy ee $\quad$ obespecheniya]. URL:
http://eizvestia.isea.ru/reader/article.aspx?id=18663 http://eizvestia.i

[18] The Federal Law "On the Subsistence Minimum in the Russian Federation" [Federalnyy zakon "O prozhitochnom minimume v Rossiyskoy Federatsii"]. URL: http://base.garant.ru/172780/ (accessed: 29.02.2016).

[19] The Federal Law "On the consumer basket in the Russian Federation" [Federalnyy zakon "O potrebitelskoy korzine v tselom po Rossiyskoy Federatsii"]. URL: (accessed: 29.02.2016).

[20] The Labour Code of the Russian Federation [Trudovoy kodeks Rossiyskoy Federatsii]. URL: (accessed: 29.02.2016).

[21] The Russian Federation branch agreement on the coal industry for the period from 01.04.2013 till 03.31.2016 years. URL: http://www.rosmintrud.ru/docs/agreements/100 (accessed: 27.03.2016).
[22] Jarosławska-Sobor S. Social potential growth of a mining company on the basis of human capital and occupational safety. Journal of Sustainable Mining. 2016. doi: 10.1016/j.jsm.2016.02.002.

[23] Selwyn B. How to come to decent work? [Kak priyti k dostoynomu trudu?]. http://www.globallabouruniversity.org/fileadmin/GLU_Column/RU_pap ers/no_161_Selwyn_RU.pdf (accessed: 01.03.2016).

[24] Brighton Labour Process Group. 1977. The Capitalist Labour Process. Capital \& Class (1). pp: 3-22.

[25] Savin G. Trade-Union experts discussed global problems in the world of labor relations system [Profsoyuznye eksperty obsudili globalnye problemy $\mathrm{v}$ mirovoy sisteme trudovykh otnosheniy]. URL: http://www.solidarnost.org/thems/vazhno/vazhno_9276.html (accessed: 01.03.2016). 